\title{
Thismia panamensis (Standl.) Jonker (Thismiaceae): first record for southern Brazil
}

\author{
Inti de Souza ${ }^{1}$ \\ 1 Federal University of Paraná, Postgraduate Program in Forest Sciences, Av. Pref. Lothário Meissner, 632, Jardim Botânico, CEP 82.590-300, \\ Curitiba, Paraná, Brazil•intidesouza@gmail.com (D) https://orcid.org/0000-0001-5658-981X
}

\begin{abstract}
A new southernmost record of Thismia panamensis (Standl.) Jonker in Brazil extends the occurrence of this species to the Atlantic Rainforest. This species was found in Parque Estadual Serra da Baitaca, in Paraná state, where other new records of mycoheterotrophic plants have recently been made. The new record highlights the wide distribution of the species, as it occurs in different ecosystems along a significant latitudinal gradient.
\end{abstract}

\section{Keywords}

Atlantic Rainforest, saprophytes, Serra do Mar

Academic editor: LuanaCalazans | Received 4 May 2021 | Accepted 3 July 2021 | Published 19 July 2021

Citation: Souza I (2021) Thismia panamensis (Standl.) Jonker (Thismiaceae): first record for southern Brazil. Check List 17 (4): 1055-1059. https://doi .org/10.15560/17.4.1055

\section{Introduction}

Thismia Griff. (Thismiaceae) is a pantropical genus of mycoheterotrophic herbs with approximately 90 species (Sahut and Tosak 2021; Siti-Munirah et al. 2021). It is particularly species-rich in Southeast Asia, where a great number of new species been recently described (Yunoh and Nikong 2019; Dančák et al. 2020a, 2020b; Silva et al. 2020; Shepeleva et al. 2020; Xu et al. 2020; Sahut and Tosak 2021; Siti-Munirah et al. 2021). In the Neotropics, its center of diversity is the Atlantic Rainforest, which harbors the majority of American Thismia (9 out of 14 species) (Maas et al. 1986; Mancinelli et al. 2012; Voloschen et al. 2013; Silva et al. 2020). In Brazil, 13 species are reported (Flora do Brasil 2020), while in Paraná state Thismia prataensis Mancinelli, C.T. Blum \& E.C. Smidt is the only species reported so far (Mancinelli et al. 2012; Smidt 2014).
Mycoheterotrophic plants grow in the litter layer of moist and well-preserved forests, where they occur in low-light conditions (Jonker 1938; Maas et al. 1986). Such habits may account for their poor documentation, with several species having been recorded only once (e.g., Thismia macahensis (Miers) F.Muell. and T. prataensis) and other species having significant gaps between records (e.g., Thismia neptunis Beccari, rediscovered after 151 years: Sochor et al. 2018) (Maas et al. 1986; Souza et al. 2019).

Some species of Thismia, along with other mycoheterotrophic plants like Dictyostega Miers and Gymnosiphon Blume (Burmanniaceae), have wide and remarkably disjunct distributions, which have usually been interpreted as an indication of their families' great antiquity (Jonker 1938; Leake 1994; Merckxet al. 2008). Thismia 
panamensis (Standl.) Jonker was recently recorded from Brazil, pushing its known distribution into the Brazilian savanna (Guilherme et al. 2016). The species has now been collected further south and into yet another biome, the Atlantic Rainforest.

\section{Methods}

Periodic expeditions made to expand knowledge of the flora of Paraná state led to the discovery of an unidentified population of a mycoheterotrophic plant at Quatro Barras, in Parque Estadual Serra da Baitaca. The specimens were deposited in the EFC Herbarium (Federal University of Paraná, Jardim Botânico Campus, Brazil). Specialized literature was used to confirm the identity of the species (Jonker 1938; Maas et al. 1986) along with specialist confirmations by Hiltje Maas-van de Kamer and Paul J.M. Maas (pers. comm. 2020). Its geographic distribution was determined from Maas et al. (1986), Fuentes et al. (2009), Guilherme et al. (2016), Villaseñor (2016), GBIF.org (2021), and Tropicos (2021). The distribution map was produced using QGIS v. 3.4.1 (QGIS Development Team 2018).

\section{Results}

Thismia panamensis (Standley) Jonker, Monogr. Burmann. 234. 1938. (Jonker 1938)

Figure 1

Materials examined. BRAZIL - Paraná • Quatro Barras, Parque Estadual Serra da Baitaca; 2523'14.06"S, 04900'34.69"W; alt. 1114 m; 04.III.2020; I. Souza 711 leg.; EFC 19525 • ibidem; 04.III.2020; I. Souza 712 leg.; EFC 19526• ibidem; 08.III.2020; I. Souza 713 leg.; EFC 19527. Figure 2.

Identification. Mycoheterotrophic herb, hyaline, 3.5$8.0 \mathrm{~cm}$ high. Tuber white, ovoid to narrowly ovoid, 4-10 $\times 2-5 \mathrm{~mm}$. Stem white, simple (seldom two), erect, 1.5 $\mathrm{mm}$ diameter. Leaves four, white, appressed in the apex of the stem, ovate, 1.5-2.5 × 1.0-2.0 mm. Flower solitary, upright. Floral tube whitish, urceolate, strongly zygomorphic, pilose inside, $5.0-6.0 \times 4.0-5.5 \mathrm{~mm}$. Throat hexagonal, $1.5 \mathrm{~mm}$ diameter. Annulus yellow, hexagonal, ornamented with three rows of yellow narrow lobes, $1 \mathrm{~mm}$ wide. Tepals just below the annulus. Shortest tepals whitish to yellowish, reflexed, ovate, apex obtuse, $2.0 \times 1.5-2.0 \mathrm{~mm}$. Largest tepals yellowish to brown, reflexed spreading, ovate, $0.5-1.0 \mathrm{~mm}$ wide, turning into a filiform appendage 6-8 mm long. Stamens six, pendulous, forming a tube just below the annulus, base sagittate, apex billobed, $1.0 \times 0.8 \mathrm{~mm}$. Style cylindric, $1.5 \mathrm{~mm}$ long. Stigma yellow, three-lobbed, covered by colourless hairs. Fruit white, cup-shaped, 5.5-6.0 × 5.5-6.0 mm.

In the region, $T$. panamensis can be distinguished from $T$. prataensis by the strongly zygomorphic floral tube, longest tepals reflexed and spreading, and lack of depressions in the annulus (versus actinomorphic floral tube, longest tepals erect, and a whorl of six depressions in annulus) (Mancinelli et al. 2012).

Distribution. Central America (Costa Rica, Mexico, and Panama), Amazonian regions of Bolivia, Colombia, Ecuador, French Guiana, and Peru, the Brazilian savanna (Goiás state), and the Atlantic Rainforest (Paraná state, Brazil) (Maas et al. 1986; Fuentes et al. 2009; Guilherme et al. 2016; Villaseñor 2016; GBIF.org 2021; Tropicos 2021). This species occurs to $1100 \mathrm{~m}$ a.s.l. in tropical rainforests of Central America to southern Brazil. Villaseñor (2016) included this species from Mexico; however, herbarium specimens and geographic coordinates could not be found online, so Mexican records were not added to the distribution map.

Habitat. The specimens were collected in a secondary dense montane rainforest, which was selectively logged. Trees high are between 15 and $20 \mathrm{~m}$, and the understory consists of a stratum of small trees and shrubs. The litter layer is about $5 \mathrm{~cm}$ and other mycoheterotrophic species were observed in the same place (Gymnosiphon tenellus (Benth.) Urb., Voyria aphylla (Jacq.) Pers. and Cymbocarpa refracta Miers). The forest grows on cambisols in a Cfb climate (temperate, humid, with mild summer) (Roderjan 1994; Alvarez et al. 2013).

Phenology. Flowering and fruiting occur year-round. Maas et al. (1986) indicated that flowering extended from June to September, but in southern Brazil, the phenology of this species is more consistent with the observations of Guilherme et al. (2016), flowering from February to April and fruiting from March to May. The observed specimens were collected with flowers and fruits in March.

\section{Discussion}

Thismia panamensis has a wide distribution, occurring from tropical rainforests to semideciduous forests in savanna environments. The population in Paraná differs from that in Goiás by the flower colour (yellowish versus purplish), but other morphological characteristics are the same. With the present record, the Atlantic Rainforest now harbours 10 out of the 14 Neotropical Thismia species.

Another species of mycoheterotrophic plant has recently been recorded in the same conservation area, signaling that the mycoheterotrophic flora of Paraná state may still be underestimated and that additional studies of mycoheterotrophic plants should be conducted at Parque Estadual Serra da Baitaca and in the Serra do Mar mountain range (Souza et al. 2019). The occurrence of $T$. panamensis in the $\mathrm{Cfb}$ climate (according to the Köppen system) suggests that the distribution of this species may extend further south in tropical rainforests under 1000 m (Köppen 1948; Roderjan 1994; Maack 2012; Alvarez et al. 2013). With only $12 \%$ of the Atlantic Rainforest remaining (Ribeiro et al. 2009), efforts to catalogue its species are extremely necessary. Even the 

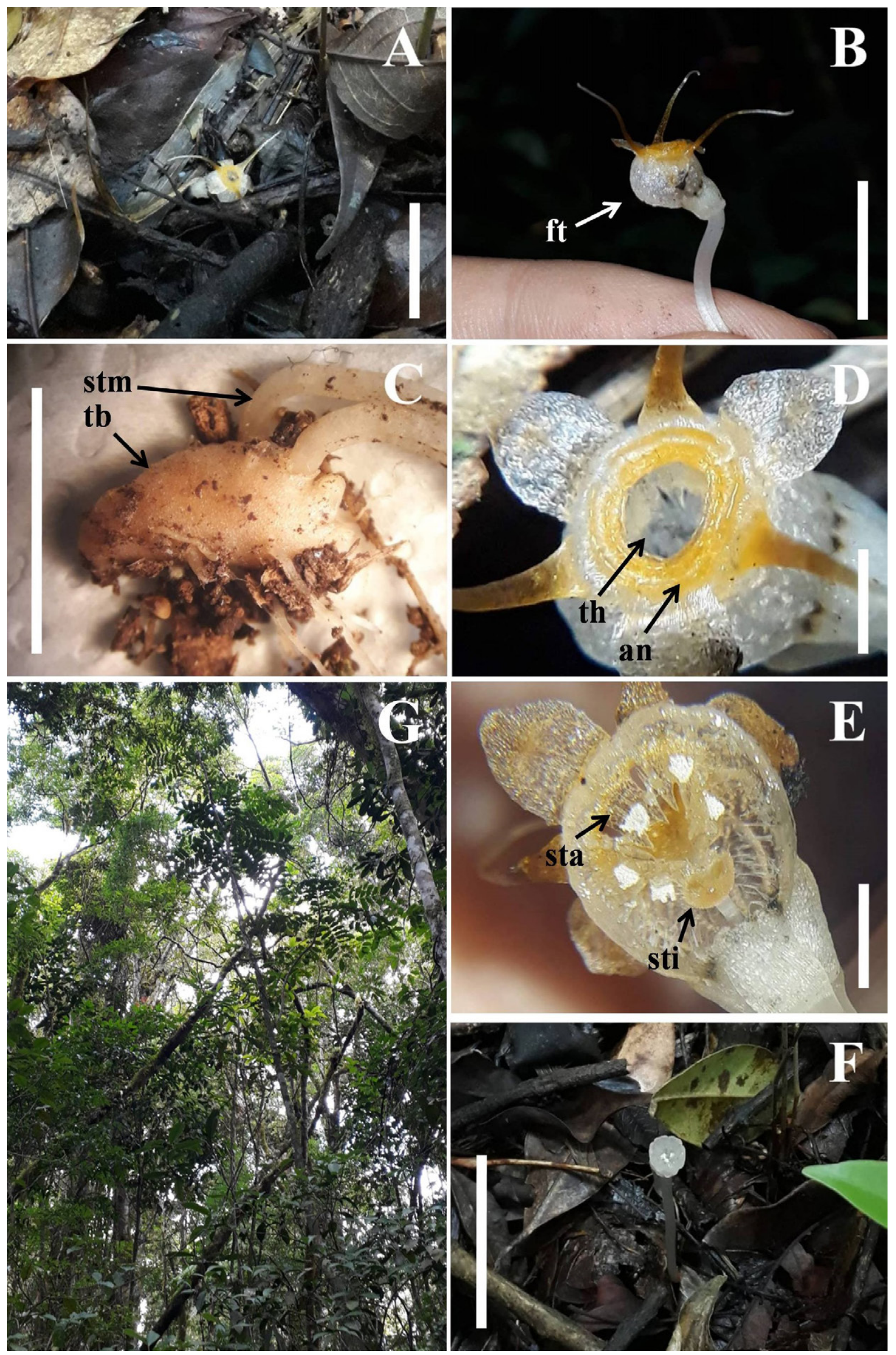

Figure 1. Thismia panamensis (Standley) Jonker. A. Individual with flower in situ. B. Zygomorphic floral tube (ft). C. Tuber (tb) with two steams (stm). D. Annulus (an) and throat (th). E. Stamens (sta) and stigma (sti) in detail. F. Individual with fruit in situ. G. Aspect of vegetation where specimens were collected. Scale bars: $A-C=10 \mathrm{~mm} ; \mathrm{D}, \mathrm{E}=1.5 \mathrm{~mm} ; \mathrm{F}=30 \mathrm{~mm}$. 


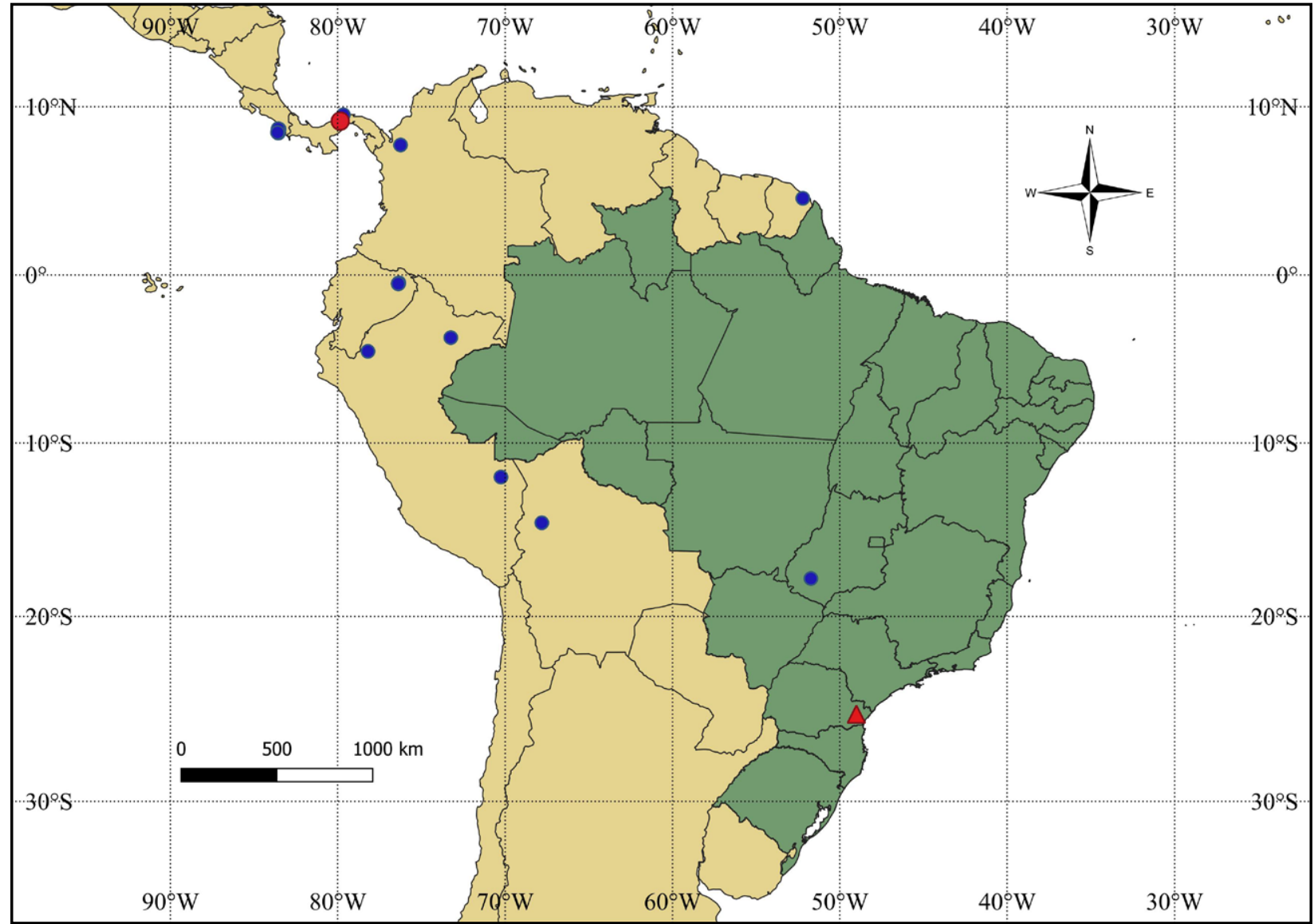

Figure 2. Geographical distribution of Thismia panamensis (Standley) Jonker in the Neotropics: type locality (red dot), other previous records (blue dots), and the new record (red triangle).

Serra do Mar region, where $36 \%$ of the Atlantic Rainforest remains intact, still suffers from human pressure (Ribeiro et al. 2009; Laurance 2009). Climate change is also a possible threat to mycoheterotrophic plants, as they depend on moist conditions for their development (Sainge et al. 2017).

\section{Acknowledgements}

My kind regards to Hiltje Maas-van de Kamer and Paul J.M. Maas for confirming the identification of Thismia panamensis. I am grateful to Prof. Christopher Thomas Blum, for being supportive of my scientific journey. I am also grateful to the reviewers and the editor.

\section{References}

Alvares CA, Stape JL, Sentelhas PC, Gonçalves JLM, Sparovek G (2013) Köppen's climate classification map for Brazil. Meteorologische Zeitschrift 22 (6): 711-728. https://doi.org/10.1127/09412948/2013/0507

Dančák M, Hroneš M, Sochor M (2020a) Thismia ornata and T. coronata (Thismiaceae), two new species from Sarawak, Borneo. Willdenowia 50: 65-76. https://doi.org/10.3372/wi.50.50106

Dančák M, Hroneš M, Sochor M (2020b) Thismia minutissima (Thismiaceae), a remarkable new mycoheterotrophic species from Sarawak, Borneo. Kew Bulletin 75:29. https://doi.org/10.1007/S12225020-09886-4

Flora do Brasil 2020 (2021) http://reflora.jbrj.gov.br/reflora/florado brasil/FB110674. Accessed on: 2021-04-29.
Fuentes AF, Miranda T, Araujo-Murakami A, Cayola L, Macía MJ, Jørgensen PM (2009) Novedades Florísticas de la Región Madidi, La Paz, Bolivia. Revista de la Sociedad Boliviana de Botánica 4 (2): 293-313.

GBIF.org (2021) GBIF occurrence download. https://doi.org/10.15468/ dl.wtuy6u. Accessed on: 2021-04-27.

Guilherme FAG, Coelho CP, Smidt EC, Gomes DC, Souza LF (2016) Thismia panamensis: first record of Thismiaceae for the Brazilian Cerrado in Goiás state. Check List 12 (2): 1877. https://doi.org/ $10.15560 / 12.2 .1877$

Jonker FP (1938) A monograph of the Burmanniaceae. Mededeelingen van het Botanisch Museum en Herbarium van de Rijks Universiteitte Utrecht 51: 1-279.

Köppen W (1948) Climatologiacom un studio de los climas de la Tierra. Fondo de CulturaEconomica, Mexico City, Mexico, 478 pp.

Laurance WF (2009) Conserving the hottest of the hotspots. Biological Conservation 142: 1137-1137. https://doi.org/10.1016/j.biocon. 2008.10.011

Leake JR (1994) The biology of myco-heterotrophic ("saprophytic") plants. New Phytologist 127: 171-216. https://doi.org/10.1111/j.14 69-8137.1994.tb04272.x

Maack R (2012) Geografia física do estado do Paraná. Universidade Estadual de Ponta Grossa, Ponta Grossa, Brazil, 526 pp.

Maas PJM, Maas-van de Kamer H, Benthem J, Snelders HCM, Rübsamen T (1986) Burmanniaceae. Flora Neotropica 42: 1-189.

Mancinelli WS, Blum CT, Smidt EC (2012) Thismia prataensis (Thismiaceae), a new species from the Brazilian Atlantic Rain Forest. Systematic Botany 37 (4): 879-882. https://doi.org/10.1600/ 036364412 X656545

Merckx V, Chatrou LW, Lemaire B, Sainge M, Huysmans S, Smets E (2008) Diversification of myco-heterotrophic angiosperms: ev- 
idence from Burmanniaceae. BMC Evolutionary Biology 8 (1): 178. https://doi.org/10.1186/1471-2148-8-178

QGIS Development Team (2018) QGIS Geographic Information System. Open Source Geospatial Foundation Project. https:/qgis.org/ en/site/. Accessed on: 2018-11-15.

Ribeiro MC, Metzger JP, Martensen AC, Ponzoni FJ, Hirota MM (2009) The Brazilian Atlantic Forest: how much is left, and how is the remaining forest distributed? Implications for conservation. Biological Conservation 142 (6): 1141-1153. https://doi.org/ 10.1016/j.biocon.2009.02.021

Roderjan CV (1994) A floresta Ombrófila densa altomontana no morro Anhangava, Quatro Barras, PR: aspectos climáticos, pedológicos e fitossociológicos. PhD dissertation, Universidade Federal do Paraná, Curitiba, Brazil, 119 pp.

Sahut C, Tosak S (2021) Thismia clavigeroides (Thismiaceae), a new mycoheterotrophic species from Thailand. Systematic Botany 46 (1): 18-23. https://doi.org/10.1600/036364421X16128061189468

Sainge MN, Chuyong GB, Peterson AT (2017) Endemism and geographic distribution of African Thismiaceae. Plant Ecology and Evolution 150 (3): 304-312. https://doi.org/10.5091/plecevo. 2017.1196

Shepeleva A, Schelkunov MI, Hroneš M, Sochor M, Dančak M, Merckx VSFT, Kikuchi IABS, Chantanaorrapint S, Suetsugu K, Tsukaya H, Mar SS, Luu HT, Li HQ, Logacheva MD, Nuraliev M (2020) Phylogenetics of the mycoheterotrophic genus Thismia (Thismiaceae: Dioscoreales) with a focus on the Old World taxa: delineation of the novel natural groups and insights into the evolution of morphological traits. Botanical Journal of the Linnean Society 20: 1-29. https://doi.org/10.1093/botlinnean/boaa017

Silva DF, Engels ME, Soares-Lopes CR (2020) Novelties in Thismia (Thismiaceae) from South Brazilian Amazon with the description of a new species. Phytotaxa 429: 261-273.
Siti-Munirah MY, Suhaimi-Miloko Z, Ahmad MIZ (2021) Thismia belumensis (Thismiaceae), a remarkable new species from the Royal Belum State Park, Gerik, Perak, Peninsular Malaysia. Phyto Keys 172: 121-134. https://doi.org/10.3897/phytokeys.172.59336

Smidt EC (2014) Thismiaceae. In: Kaehler M, Goldenberg R, Evangelista PHL, Ribas OS, Vieira AOS, Hatschbach GG (Eds.) Plantas Vasculares do Paraná. Universidade Federal do Paraná, Curitiba, Brazil, 94.

Sochor M, Egertová Z, Hroneš M, Dančák M (2018) Rediscovery of Thismia neptunis (Thismiaceae) after 151 years. Phytotaxa 340 (1): 071-078. http://doi.org/10.11646/phytotaxa.340.1.5

Souza I, Blum CT, Brotto ML (2019) First record of Gymnosiphon tenellus (Benth.) Urb. (Burmanniaceae) in Paraná state and southern Brazil. Check List 15 (5): 863-866. http://doi.org/10.15560/ 15.5.863

Tropicos (2021) http://www.tropicos.org/. Accessed on: 2021-04-29.

Villaseñor JL (2016) Checklist of the native vascular plants of Mexico. Revista Mexicana de Biodiversidad 87 (3): 559-902. https://doi. org/10.1016/j.rmb.2016.06.017

Voloschen TD, Engels ME, Assunção PACL, Smidt EC(2013) Thismia singer (Thismiaceae), an augmented description and first record for Brazil. Brazilian Journal of Botany 36: 309-312. https://doi. org/10.1007/s40415-013-0037-y

Xu H, Yang H, Lin M, Corrales A, Hogan JA, Li, Y, Fang S (2020) Thismia jianfenglingensis (Thismiaceae), a new species of the fairy lantern from Hainan Islan, China. Phytotaxa 429 (2): 179 185. https://doi.org/10.11646/phytotaxa.429.2.9

Yunoh SMM, Nikong D (2019) Thismia domei and T. terengganuensis (Thismiaceae), two new species, and T. javanica, a new record from Terengganu, Peninsular Malaysia. Phyto Keys 124: 123-137. https://doi.org/10.3897/ phytokeys.124.34728 